\title{
New records of geometrid moths (Lepidoptera: Geometridae) from Myanmar based on DNA barcodes and morphological data
}

\author{
Vitaly M. Spitsyn,,${ }^{1,2}$, Nikita I. Bolotov, ${ }^{1,2}$ Alexander V. Kondakov, ${ }^{1,2}$ Alena A. Tomilova, ${ }^{1}$ Nhi Thi \\ Pham $^{3}$ \\ 1 Russian Museum of Biodiversity Hotspots, IBIGER - Institute of Biogeography and Genetic Resources, Federal Center for Integrated Arctic \\ Research, Russian Academy of Sciences, Severnaya Dvina Emb. 23, 163000 Arkhangelsk, Russian Federation. 2 Northern (Arctic) Federal \\ University, Severnaya Dvina Emb. 17, 163002 Arkhangelsk, Russian Federation. 3 Institute of Ecology and Biological Resources, Vietnam \\ Academy of Science and Technology, 18 Hoang Quoc Viet Road, Cau Giay, Hanoi, Vietnam. \\ Corresponding author: Vitaly M. Spitsyn, vitalik91993@yandex.ru
}

\begin{abstract}
An integrative study of the Indo-Burmese Geometridae in the collection of the Russian Museum of Biodiversity Hotspots (RMBH, Russia) revealed six newly recorded species for the fauna of Myanmar, i.e., Plutodes costatus (Butler, 1886), Pogonopygia nigralbata Warren, 1894, Mixochlora vittata (Moore, 1867), Pelagodes bellula Han \& Xue, 2011, Agathia carissima Butler, 1878 and A. codina Swinhoe, 1892. The occurrence of P. bellula is the first record of this taxon outside the Tibetan Plateau. Our findings highlight that the distribution of several Oriental geometrids could be broader than was previously suggested.
\end{abstract}

Key words

BOLD database; DNA barcoding; Ennominae; Geometrinae; Indo-Burma Region; integrative taxonomy.

Academic editor: Lívia Rodrigues Pinheiro | Received 13 October 2016 | Accepted 21 June 2017 | Published 6 October 2017

Citation: Spitsyn VM, Bolotov NI, Kondakov AV, Tomilova AA, Pham NT (2017) New records of geometrid moths (Lepidoptera: Geometridae) from Myanmar based on DNA barcodes and morphological data. Check List 13 (5): 569-576. https://doi.org/10.15560/13.5.569

\section{Introduction}

The Indo-Burma Region represents one of the world's greatest biodiversity hotspots (Martens 2015). However, the Indo-Burmese fauna of Lepidoptera is poorly known, particularly concerning large, complex taxonomy such as Geometridae. There are some works covering the geometrid fauna of certain regions such as northern India (Hampson 1895), China (Han and Xue 2011a) and Borneo (Holloway 1993, 1996), but there is a lack of recent publications on the fauna of Myanmar. Notwithstanding, in a book by Hampson (1895) which is mainly focused on geometrid fauna of India, there are some data in a poorly detailed study of Myanmar geometrid moths.
In available sources, the distributions of certain species are often described using vague locations, for example, the Himalayas (Holloway 1993, 1996, Cerny and Pinratana 2009, Bucsek 2012), which is actually the world's greatest mountain system that is bordered by a number of countries, including China, India, Nepal, Bhutan, and others. Such an approach can sometimes cause uncertainty during the compiling of the national checklists of Lepidoptera fauna. Accordingly, this uncertainty in the actual distribution range of taxa makes the environmental protection activity a much more complicated task. Many examples of Asian Lepidoptera species have large gaps of areas over entire countries in their distribution ranges, 
until recently (Monastyrskii and Devyatkin 2000, Spitsyn et al. 2015).

In the present study, we report new distribution records of six geometrid species that are recorded from Myanmar for the first time. To confirm these new records, we performed DNA barcoding for 10 specimens, which were initially separated based on the morphological investigation.

\section{Methods}

Morphological studies. The Indo-Burmese Geometridae were studied in the collection of the Russian Museum of Biodiversity Hotspots (RMBH hereafter), Institute of Biogeography and Genetic Resources, Federal Center for Integrated Arctic Research, Russian Academy of Sciences, Arkhangelsk, Russia. The sampling localities are listed in Table 1. The specimens were prepared according to a standard protocol (Schauff 2001). The genitalia dissections were performed using common methods for Lepidoptera (Robinson 1976). The abdomen was macerated in hot $10 \% \mathrm{KOH}$ solution for 3-5 minutes. The extracted genitalia were mounted in permanent slides with Histofluid $^{\circledR}$ (Paul Marienfeld GmbH \& Co., Germany). Specimens were photographed using a digital camera (Canon EOS 650D, Canon, Japan). Genitalia slides were photographed using a stereo microscope (SteREO Discovery.V8, Carl Zeiss, Germany).

DNA barcoding. Total DNA was extracted from a single leg of each dry specimen according to a standard phenol/chloroform procedure (Sambrook et al. 1989). The mitochondrial cytochrome $c$ oxidase subunit I gene $(C O I)$ was amplified and sequenced using primers C1-J-1718 (forward primer: 5' GGAGGATTTGGAAATTGATTAGTTCC 3') and C1-N-2329 (reverse primer: 5' ACTGTAAATATATGATGAGCTCA 3') (Simon et al. 1994). The PCR mix contained approximately $200 \mathrm{ng}$ of total cell DNA, $10 \mathrm{pmol}$ of each primer, $200 \mu \mathrm{mol}$ of each dNTP, $2.5 \mu$ of PCR buffer (with $20 \mathrm{mmol} \mathrm{MgCl}_{2}$ ), 0.8 units Taq DNA polymerase (SibEnzyme Ltd., Novosibirsk, Russia), and $\mathrm{H}_{2} \mathrm{O}$ was added for a final volume of $25 \mu \mathrm{l}$. Temperature cycling was as follows: $95{ }^{\circ} \mathrm{C}(4$ min), 40 cycles of $95^{\circ} \mathrm{C}(50 \mathrm{sec}), 48^{\circ} \mathrm{C}(50 \mathrm{sec}), 72^{\circ} \mathrm{C}$ $(50 \mathrm{sec})$ and a final extension at $72{ }^{\circ} \mathrm{C}(5 \mathrm{~min})$. Forward and reverse sequence reactions were performed directly on purified PCR products using the ABI PRISM ${ }^{\circledR}$ BigDye $^{\mathrm{TM}}$ Terminator v. 3.1 reagents kit and run on an ABI PRISM ${ }^{\circledR} 3730$ DNA (Thermo Fisher Scientific Inc., Waltham, MA, USA). The resulting sequences were checked using a sequence alignment editor (BioEdit version 7.2.5, Hall 1999).
All new sequences were uploaded to the NCBI GenBank database (Table 2). The taxonomic affinities of our nucleotide sequences were identified using the Basic Local Alignment Search Tool, BLAST (Johnson et al. 2008) and the Barcode of Life Data Systems (BOLD Systems v3; see Ratnasingham and Hebert 2007).

Identification. The moth specimens were identified with appropriate keys (Han and Xue 2011a, 2011b, Holloway 1993, 1996) based on the external diagnostic features and male genitalia morphology. Dr H.-X. Han (Key Laboratory of Zoological Systematics and Evolution, Institute of Zoology, Chinese Academy of Sciences) confirmed our identification of Pelagodes bellula from Myanmar.

\section{Results}

In this study 10 new COI nucleotide sequences of six geometrid species were obtained (Table 2). As aforementioned, each of the six species is recorded in Myanmar for the first time. Additionally, we used a dataset of 84 barcode sequence records of these taxa that was obtained via the BOLD database.

\section{Taxonomic account}

\section{Subfamily Ennominae}

Plutodes costatus (Butler, 1886): Figures 1, 2, 15

Garaeus costatus Butler 1886: 53.

Plutodes costatus Butler 1886: 53.- Hampson 1895: 161; Parsons et al. 1999: 767; Stüning 2010: 76.

Plutodes triangularis Warren 1893: 388.

Material examined. Myanmar: MY1: $1 \hat{\jmath}, 1 q$, 18-19.iii.2014, Bolotov \& Spitsyn leg. (RMBH, vouchers: Sph0326 and Sph0327).

Diagnosis. This species is similar to $P$. thorbeni Stüning, 2010, an endemic of Sulawesi, but differs by narrower yellow edging of the forewing and longer saccular process in the male genitalia.

Distribution. India: Darjeeling, Sikkim, and Naga Hills; Thailand; Indonesia: Sumatra (Hampson 1895, Parsons et al. 1999, Koçak and Kemal 2010, Stüning 2010) and Myanmar: Kachin.

DNA barcoding. With respect to the BOLD records, specimens from Myanmar show the closest affinity to a specimen from Bhutan with genetic distance of $0.22 \%$ (Table 2). In general, 26 nearest neighbor sequences with distances up to $0.95 \%$ were recorded using the BOLD database. The nearest neighbors were collected from Bhutan, Thailand, Myanmar, China, Vietnam, Malaysia and Indonesia.

Pogonopygia nigralbata Warren, 1894: Figures 3-6, 16 Pogonopygia nigralbata Warren 1894: 681.-Holloway 1993: 175.

Table 1. Sampling sites in Kachin state, Myanmar

\begin{tabular}{llcccl}
\hline Code & Locality name & Latitude $\left({ }^{\circ} \mathbf{N}\right)$ & Longitude $\left({ }^{\circ} \mathbf{E}\right)$ & Altitude $(\mathbf{m})$ & Habitat \\
\hline MY1 & Wasandum village & 27.4949 & 097.1900 & 850 & Mountain rainforest with bamboo patches at the river valley \\
MY2 & Masandum village & 27.4909 & 097.3350 & 420 & Mountain rainforest with bamboo patches at the river valley \\
MY3 & Malaria village & 27.5701 & 097.3716 & 470 & Edge of mountain rainforest connected with grass pasture \\
\hline
\end{tabular}




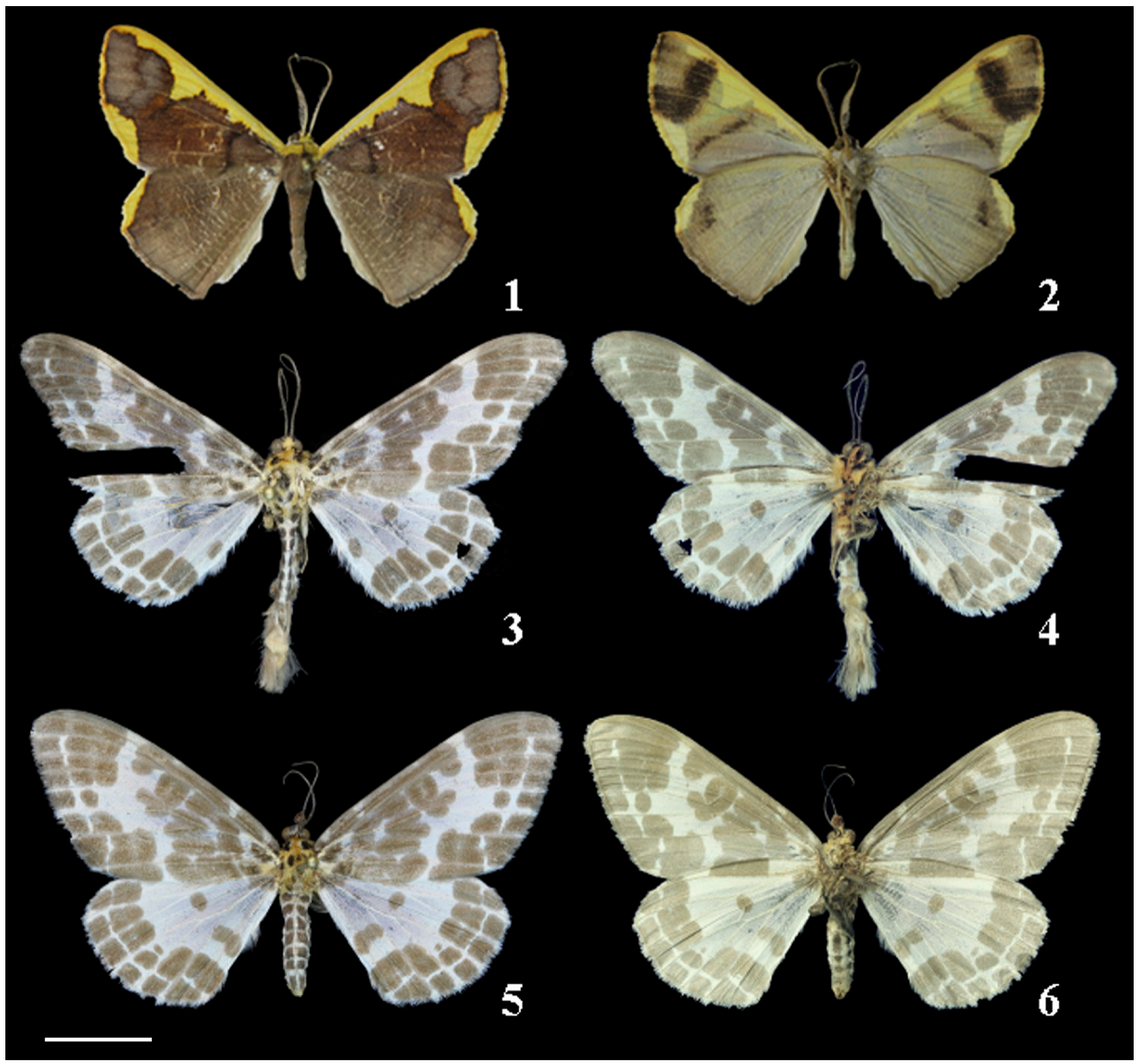

Figures 1-6. Subfamily Ennominae. 1, 2. $\widehat{\jmath}$ Plutodes costatus (1, upper side; 2 , underside). 3, 4. $\widehat{\jmath}$ Pogonopygia nigralbata (3, upper side; 4 , underside). 5, 6. + Pogonopygia nigralbata (5, upper side; 6, underside). Scale bar: 10 mm. Photograph by V.M. Spitsyn.

Pogonopygia nigralbata attenuata Warren 1897: 240.-Holloway 1976: 84.

Dilophodes elegans sinica Chu 1981: 123 [identification error].

Material examined. Myanmar: MY1: $1 \hat{\jmath}, 4 \circ, 18-19$. iii.2014, Bolotov \& Spitsyn leg. (RMBH, vouchers: Sph0215, Sph0216, Sph0217, Sph0678, and Sph0679).

Diagnosis. This species is similar to numerous congeners but differs by marking patterns of the hindwing. However, DNA barcoding is the best way for its reliable identification.

Distribution. Japan; China; India: Meghalaya (Khasi Hills); Vietnam; Philippines: Luzon; Malaysia; and Indonesia: Sumatra and Borneo (Chu 1981, Holloway 1993, Parsons et al. 1999, Suzuki et al. 2015) and Myanmar: Kachin.

DNA barcoding. With respect to the BOLD records, specimens from Myanmar revealed the closest affinity to specimens from China and Vietnam with genetic distance of $0.22 \%$ (Table 2). In general, 34 nearest neighbor sequences with distances up to $1.89 \%$ were recorded using the BOLD database. The nearest neighbors were collected from Vietnam, China, Japan, Malaysia, and Indonesia.
Remarks. Chu (1981: fig. 865) illustrated this species but erroneously identified it as Dilophodes elegans sinica, although these two taxa have clear differences in forewing morphology.

\section{Subfamily Geometrinae}

Mixochlora vittata (Moore, [1868]): Figures 7, 8, 20

Geometra vittata Moore [1868]: 636.

Tanaorhinus prasinus Butler 1879: 438.

Tanaorhinus vittata Moore [1868]: 636.—Prout 1912: 16; Chu 1981: 118. Tanaorhinus vittata sumatrensis Prout 1933: 77.

Mixochlora vittata kalisi Prout 1935: 224.

Mixochlora vittata Moore [1868]: 636.- - Holloway 1976: 61; Holloway 1996: 217; Han and Xue 2011a: 221.

Material examined. Myanmar: MY1: 1ڤึ, 18-19. iii.2014, Bolotov \& Spitsyn leg. (RMBH, voucher no.: Sph 0275).

Diagnosis. This species is similar to M. argentifusa, but differs by more acute apex of the forewing.

Distribution. Nepal; Bhutan; India: Himachal Pradesh, Sikkim, Assam, Meghalaya, and Uttarakhand; China: Jiangsu, Zhejiang, Hubei, Jiangxi, Hunan, Fujian, Taiwan, Guangdong, Hainan, Sichuan, and Yunnan; 


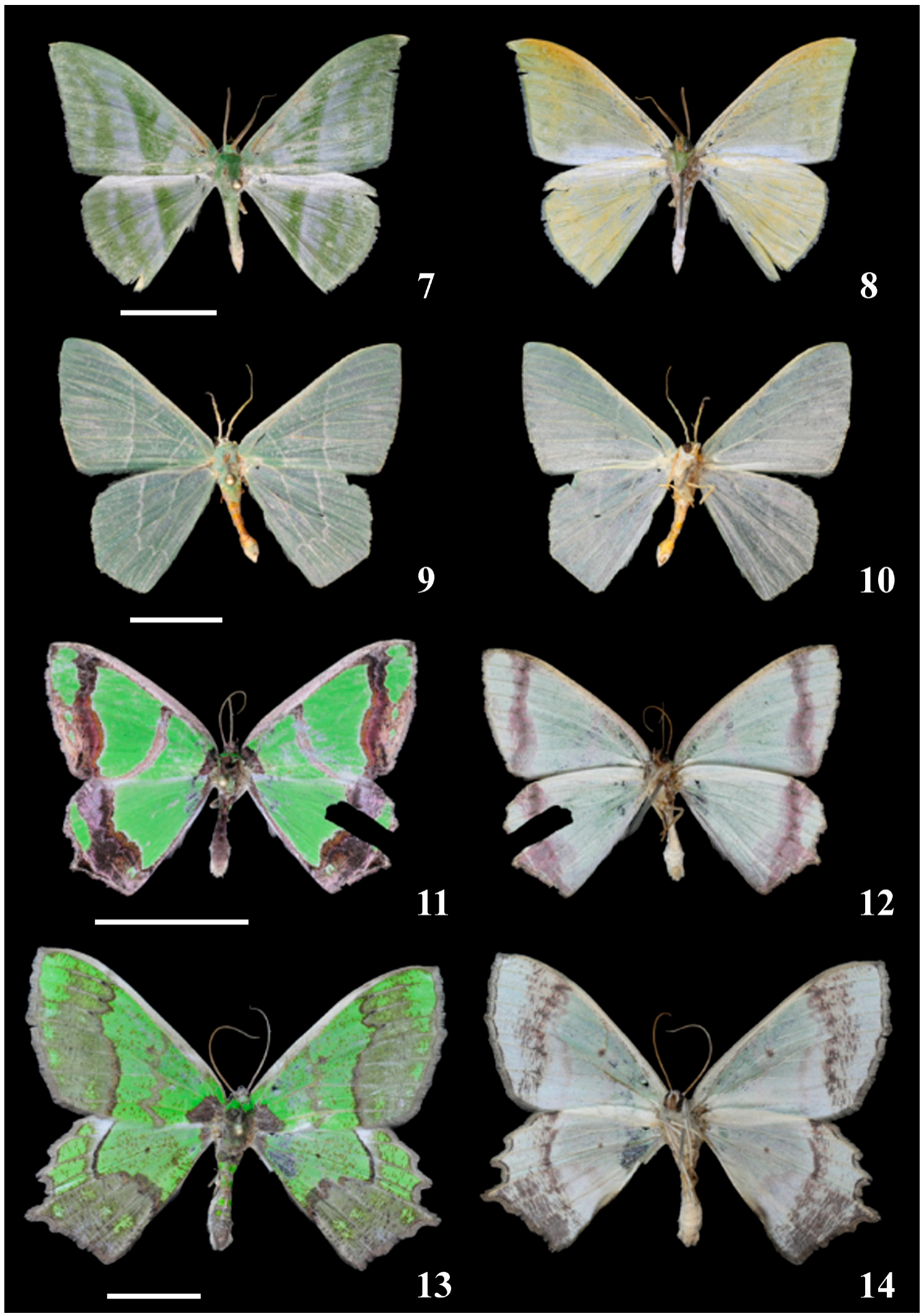

Figures 7-14. Subfamily Geometrinae. 7, 8. $\delta$ Mixochlora vittata (7, upper side; 8, underside). 9, 10. $\delta$ Pelagodes bellula (9, upper side; 10,

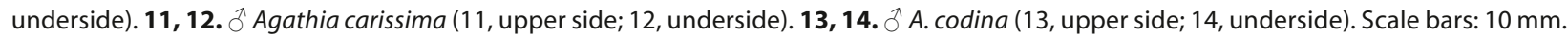
Photograph by V.M. Spitsyn.

Korea: Jeju island; Japan: Honshu, Shikoku, Kyushu, Tsushima, and Yakushima; Thailand: Chiang Mai; Malaysia; Indonesia: Sumatra, Borneo, and Java; and Philippines (Holloway 1996, Smetacek 2008, Jung 2009, Han and Xue 2011a, Suzuki et al. 2015) and Myanmar: Kachin.
DNA barcoding. With respect to the BOLD records, a specimen from Myanmar reveals the closest affinity to a specimen from Thailand with genetic distance of $0.22 \%$ (Table 2). In general, 10 nearest neighbor sequences with distances up to $2.46 \%$ were recorded using the BOLD 


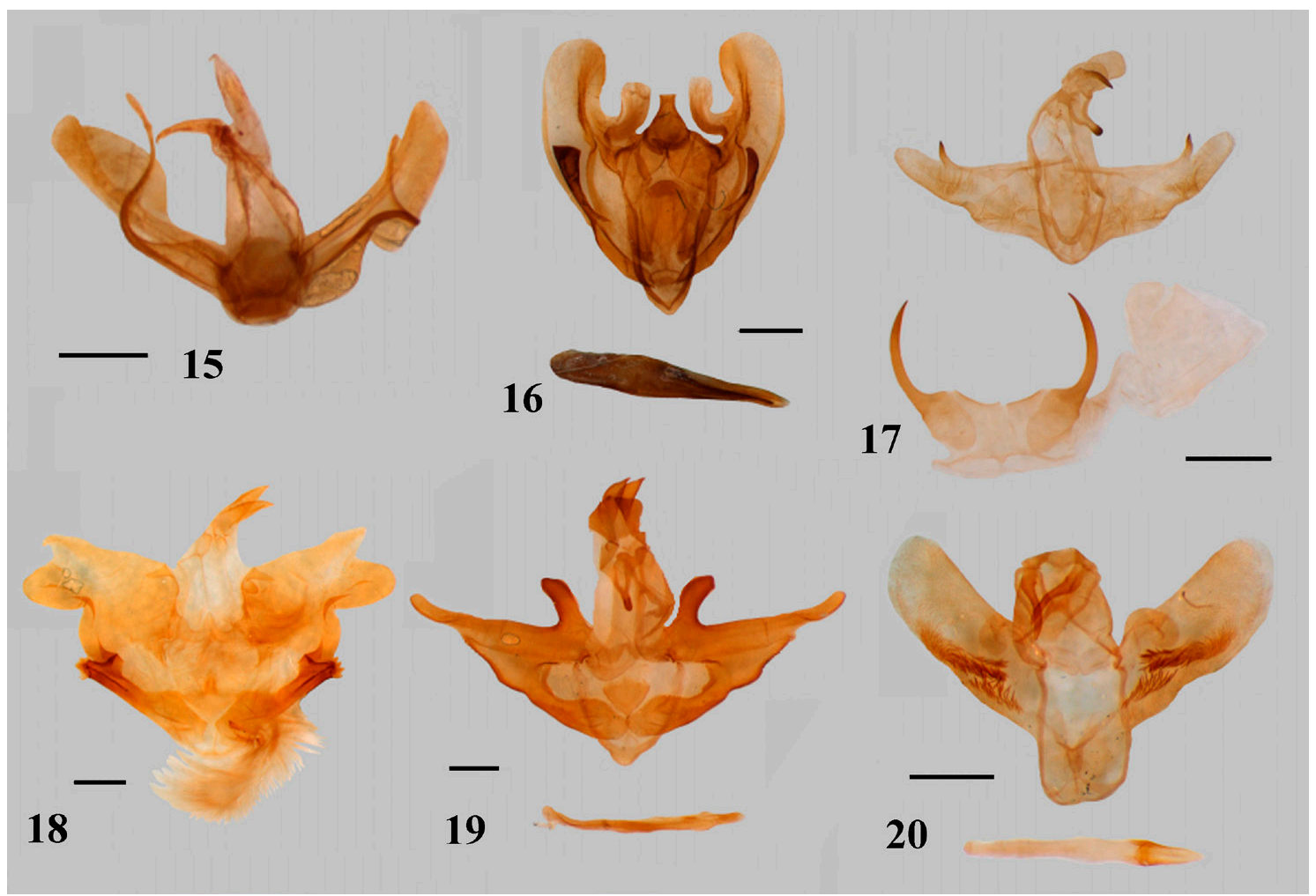

Figures 15-20. Subfamily Ennominae. 15. $\delta$ Plutodes costatus (male genitalia and phallus). 16. $\lesssim$ Pogonopygia nigralbata (ditto). Subfamily

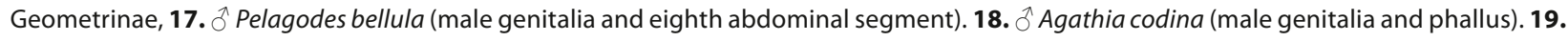
$\delta^{\lambda}$ A. carissima (ditto). 20. $\overbrace{}^{\top}$ Mixochlora vittata (ditto). Scale bars: $1 \mathrm{~mm}$. Photograph by V.M. Spitsyn.

database. The nearest neighbors were collected from Thailand, Nepal, Bhutan, Philippines, Malaysia, and Indonesia.

Remarks. Holloway (1996) illustrated the male genitalia of Mixochlora vittata as those of $M$. argentifusa and vice versa, likely because of a typographic error. Actually, the genitalia of the former species are given in Holloway's fig. 169, while the genitalia of M. argentifusa are shown in figure 168 (Holloway 1996).

Pelagodes bellula Han \& Xue, 2011: Figures 9, 10, 17, 21, 22

Pelagodes bellula Han and Xue 2011b: 37.

Material examined. Myanmar: MY2: 20, 13.iii.2014, Bolotov \& Spitsyn leg. (RMBH, vouchers: Sph 0280 and Sph 0281).

Diagnosis. Pelagodes bellula shows great similarity with $P$. aucta, another species from India. In this case, the only reliable way to do a correct species identification is to compare rate of sclerotization in the male genitalia: $P$. bellula has lesser sclerotization compared with $P$. aucta (Han and Xue 2011b).

Distribution. China: Tibet (Han and Xue 2011b) and Myanmar: Kachin.

DNA barcoding. With respect to the BOLD records, specimens from Myanmar show the closest affinity to a specimen of Thalassodes veraria (this species is currently placed within Pelagodes: see Han and Xue 2011b) from Vietnam with genetic distance of $0.45 \%$ (Table 2). No other nearest neighbors were recorded.

Remarks. Our new record marks the occurrence of
Pelagodes bellula outside of the territory of China for the first time (Fig. 21). We suggest that the species may also range in Vietnam. However, since the discussed specimen from the BOLD Systems dataset was identified as Thalassodes veraria, this question needs further clarification.

Agathia carissima Butler, 1878: Figures 11, 12, 19

Agathia carissima Butler 1878: 50.-Inoue 1961: 32; Chu 1981: 119; Han and Xue 2011a: 539.

Agathia lacunaria Hedemann 1879: 512

Agathia prasina Swinhoe 1893: 219.

Material examined. Myanmar: MY1: 1ðへ, 18-19. iii.2014, Bolotov \& Spitsyn leg. (RMBH, voucher: Sph 0277).

Diagnosis. This species differs from all the other congeners by well-developed costal processes of the valva in the male genitalia.

Distribution. Russia: Primorsky region, Khabarovsk region, and South Kuril Islands; Japan: Hokkaido, Honshu, Shikoku, and Kyushu; China: Heilongjiang, Jilin, Liaoning, Inner Mongolia, Beijing, Shanxi, Henan, Shaanxi, Gansu, Zhejiang, Hubei, Hunan, Sichuan, and Yunnan; Korean Peninsula; India (Mironov et al. 2008, Han and Xue 2011a, Suzuki et al. 2015) and Myanmar: Kachin.

DNA barcoding. With respect to the BOLD records, a specimen from Myanmar reveals the closest affinity to specimens from Laos and China with genetic distance of $0.45 \%$ (Table 2). Three additional nearest neighbor sequences with distances up to $0.71 \%$ were recorded 


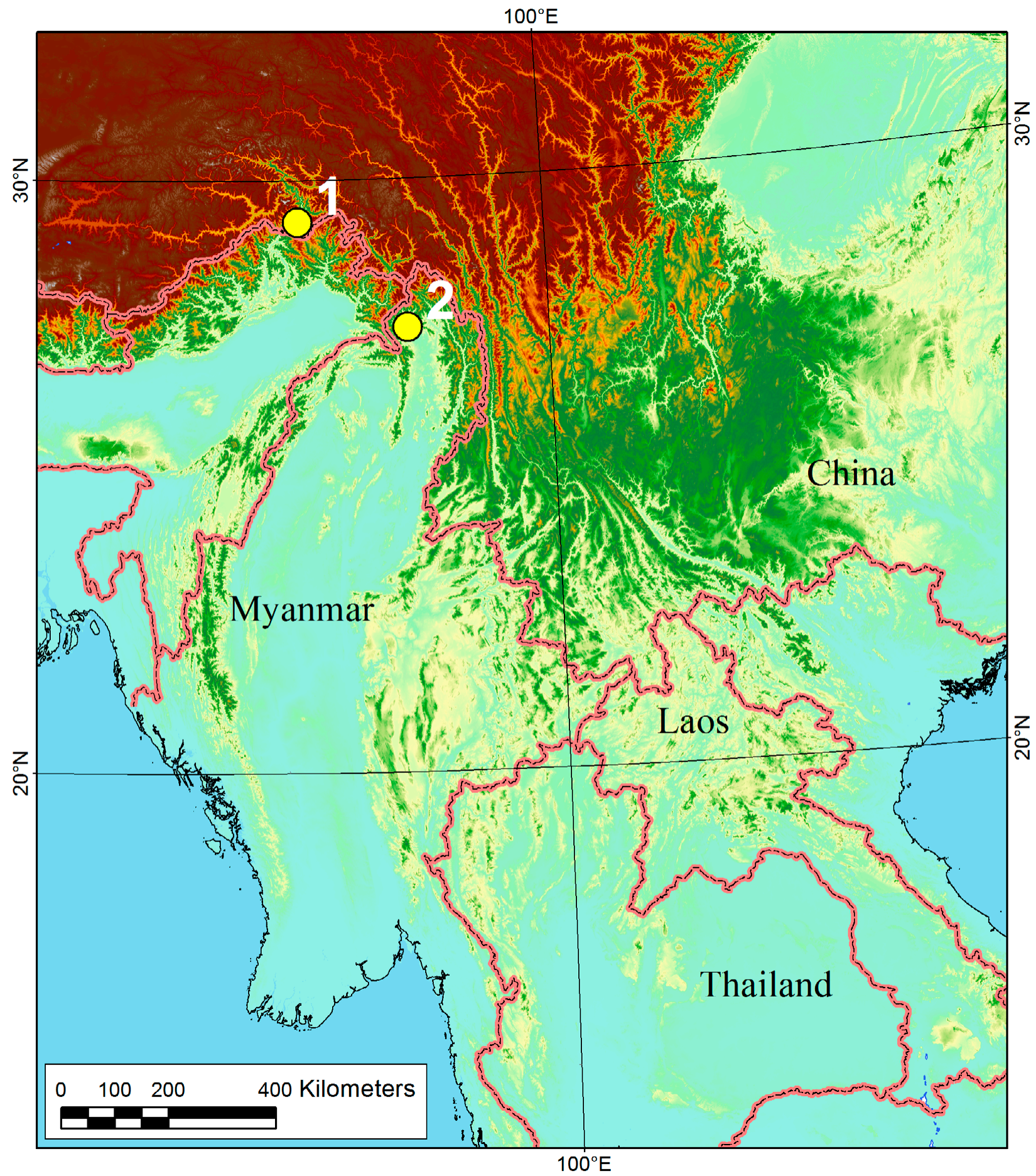

Figure 21. Known records of Pelagodes bellula Han \& Xue 2011: (1) type locality: China, southern Tibet, near Yarang village (Han \& Xue 2011b); (2) our record: Myanmar, Kachin, Masandum village.

from Thailand. The BOLD records from Laos and Thailand, which have been deposited under other taxonomic names (i.e., Agathia lycaenaria and A. laetata), expand the known species range.

\section{Agathia codina Swinhoe, 1892: Figures 13, 14, 18} Agathia codina Swinhoe 1892: 7.- Holloway 1996: 229; Han and Xue 2011a: 541

Agathia codina australis Prout 1916: 200.

Material examined. Myanmar: MY1: 1ठ̄, 18-19.iii. 2014, MY3: 1ठ̄, 14.iii.2014, Bolotov \& Spitsyn leg.
(RMBH, vouchers: Sph 0278 and Sph 0279).

Diagnosis. This species differs from all the other congeners by the male genitalia structure and by narrow submarginal line on the hindwing, which is black with white outer margin.

Distribution. India: Meghalaya, Assam, Sikkim; China: Hainan, Yunnan; Vietnam; Thailand; Malaysia; Indonesia: Sumatra, Borneo (Holloway 1996, Han and Xue 2011a) and Myanmar: Kachin.

DNA barcoding. With respect to the BOLD records, 
Table 2. List of the mitochondrial $\mathrm{CO}$ sequences of Geometridae obtained in the present study

\begin{tabular}{|c|c|c|c|c|c|}
\hline Species & $\begin{array}{l}\text { Location } \\
\text { site code }\end{array}$ & $\begin{array}{l}\text { RMBH } \\
\text { voucher no. }\end{array}$ & $\begin{array}{l}\text { NCBI Genbank } \\
\text { COI acc. no. }\end{array}$ & $\begin{array}{l}\text { List and number of available nearest neighbor } \\
\text { COI sequences with K2P distance (\%)* }\end{array}$ & $\begin{array}{l}\text { Region of origin of the } \\
\text { nearest neighbors* }\end{array}$ \\
\hline $\begin{array}{l}\text { Plutodes costatus } \\
\text { (Butler, 1886) }\end{array}$ & MY1 & $\begin{array}{l}\text { Sph0326 } \\
\text { Sph0327 }\end{array}$ & $\begin{array}{l}\text { KU923772 } \\
\text { KU923773 }\end{array}$ & $\begin{array}{l}\text { Plutodes costatus }(0.22-0.89 ; N=17), P . \mathrm{sp} .(0.7-0.95 ; \\
N=6), P . \operatorname{sp} . \text { AH01My }(0.22 ; N=1), P . \mathrm{sp} . \mathrm{AH} 02(0.45 ; N \\
=1) \text {, and Geometridae sp. }(0.46 ; N=1)\end{array}$ & $\begin{array}{l}\text { Bhutan, Thailand, } \\
\text { Myanmar, China, Vietnam, } \\
\text { Malaysia, and Indonesia }\end{array}$ \\
\hline $\begin{array}{l}\text { Pogonopygia } \\
\text { nigralbata Warren, } \\
1894\end{array}$ & MY1 & $\begin{array}{l}\text { Sph0215 } \\
\text { Sph0216 } \\
\text { Sph0217 }\end{array}$ & $\begin{array}{l}\text { KU923764 } \\
\text { KU923765 } \\
\text { KU923766 }\end{array}$ & $\begin{array}{l}\text { Pogonopygia nigralbata }(0.22-2.01 ; N=10), P . s p . \\
(0.84-1.89 ; N=23) \text {, and } P . \text { attenuata }(1.79 ; N=1)\end{array}$ & $\begin{array}{l}\text { Vietnam, China, Japan, } \\
\text { Malaysia, and Indonesia }\end{array}$ \\
\hline $\begin{array}{l}\text { Mixochlora vit- } \\
\text { tata (Moore, 1867) }\end{array}$ & MY1 & Sph0275 & KU923767 & $\begin{array}{l}\text { Mixochlora vittata }(0.22-1.79 ; N=6), \text { M. vittata } \\
\text { sumatrensis }(1.34-1.42 ; N=2), M . \text { vittata kalisi }(2.46 ; N \\
=1) \text {, and } M . \text { sp. }(1.56 ; N=1)\end{array}$ & $\begin{array}{l}\text { Thailand, Nepal, Bhutan, } \\
\text { Philippines, Malaysia, and } \\
\text { Indonesia }\end{array}$ \\
\hline $\begin{array}{l}\text { Pelagodes bellula } \\
\text { Han \& Xue, } 2011\end{array}$ & MY2 & $\begin{array}{l}\text { Sph0280 } \\
\text { Sph0281 }\end{array}$ & $\begin{array}{l}\text { KU923770 } \\
\text { KU923771 }\end{array}$ & Thalassodes veraria $(0.45 ; N=1)$ & Vietnam \\
\hline $\begin{array}{l}\text { Agathia carissima } \\
\text { Butler, } 1878\end{array}$ & MY1 & Sph0277 & KU923768 & $\begin{array}{l}\text { Agathia carissima }(0.5-0.67 ; N=2) \text {, A. lycaenaria } \\
(0.45 ; N=2), A . \text { laetata }(0.71 ; N=1) \text {, and } A . \mathrm{sp} . \\
\text { AH01 La }(0.45 ; N=1)\end{array}$ & Laos, China, and Thailand \\
\hline $\begin{array}{l}\text { Agathia codina } \\
\text { Swinhoe, } 1892\end{array}$ & $\begin{array}{l}\text { MY1 and } \\
\text { MY3 }\end{array}$ & Sph0279 & KU923769 & $\begin{array}{l}\text { Agathia codina }(0.67-0.78 ; N=2), \text { A. australis }(0.89 \\
N=1), A . \text { sp. }(0.79-1.57 ; N=3), \text { and Geometridae sp. } \\
(1.34 ; N=1)\end{array}$ & $\begin{array}{l}\text { Vietnam, Thailand, } \\
\text { Malaysia, and Indonesia }\end{array}$ \\
\hline
\end{tabular}

*Based on the BOLD database.

the specimen from Myanmar reveals the closest affinity to the specimen from Vietnam with genetic distance of $0.67 \%$ (Table 2). Six additional nearest neighbor sequences with distances up to $1.57 \%$ were recorded from Thailand, Malaysia, and Indonesia.

\section{Discussion}

An integrative study of the Indo-Burmese Geometridae in the RMBH collection revealed six newly recorded species for the fauna of Myanmar. Among them, five species are common and widespread (i.e., Plutodes costatus, Pogonopygia nigralbata, Mixochlora vittata, Agathia carissima and Agathia codina).

By contrast, Pelagodes bellula is a recently described species, which was known by four type specimens collected near Yarang $\left(29.296^{\circ} \mathrm{N}, 095.279^{\circ} \mathrm{E}\right)$ in southern Tibet (Han and Xue 2011b). The distance between the Tibetan locality and our collection point in Kachin is roughly $280 \mathrm{~km}$ (Fig. 21). The elevations of the species localities in Tibet are much greater than those in Kachin (790-1090 m and $420 \mathrm{~m}$, respectively). With respect to our data, the range of $P$. bellula is much broader than was previously assumed and this species may also be found in northern India (e.g., in Arunachal Pradesh).

The documentation of moths and reporting their distribution with specific localities will help the ecologists to formulate the conservation plans. We presume that our study, which applies an integrative taxonomic approach to report new distributional records, will encourage new discoveries.

\section{Acknowledgements}

The authors wish to thank Dr H.-X. Han (Institute of Zoology, Chinese Academy of Sciences, China) for confirming the identification of Pelagodes bellula. Our gratitude also goes to Ms L.V. Shestakova, who assisted in producing images of specimens with a microscope, to $\mathrm{Dr}$

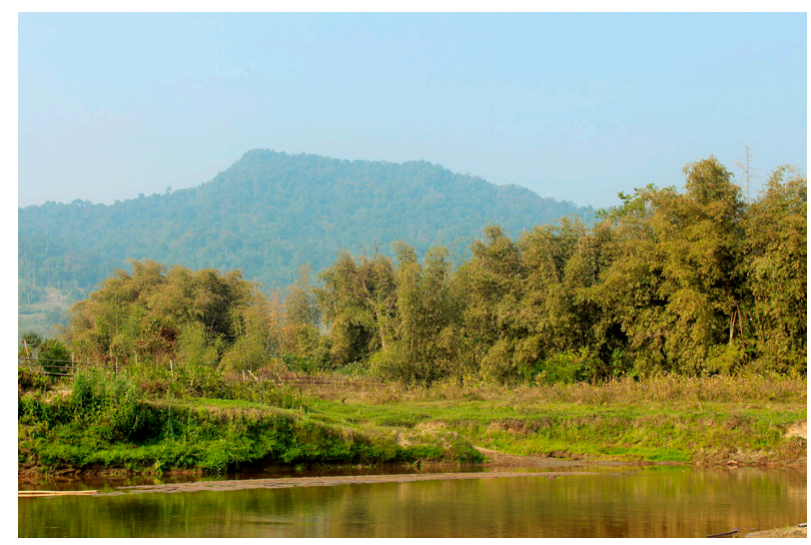

Figure 22. Mountain rainforest with bamboo patches at the river valley in Kachin State, Myanmar, habitat of Pelagodes bellula Han \& Xue 2011. Photograph by V.M. Spitsyn.

I.N. Bolotov, who helped in manuscript revision, and also to Y.E. Kogut, who created a map for the study. All necessary permits were obtained for the field trip from the local authorities of Putao District, Kachin state, Myanmar. This study was supported by the Federal Agency for Scientific Organizations (no. 0410-2014-0028) and a grant from the President of Russia (no. MD-7660.2016.5).

\section{Authors' Contributions}

VMS wrote the text, identified, collected and dissected specimens, NIB and NTP wrote the text as co-authors, AVK and AAT performed the molecular analyses.

\section{References}

Bucsek K (2012) Erebidae, Arctiinae (Lithosiini, Arctiini) of Malay Peninsula, Malaysia. Institute of Zoology SAS, Bratislava, $170 \mathrm{pp}$. Butler AG (1878) Illustrations of Typical Specimens of Lepidoptera Heterocera in the Collection of British Museum. Vol. 2. Taylor and Francis, London, 62 pp.

Butler AG (1879) Descriptions of new species of Lepidoptera from Japan. Annals and Magazine of Natural History 5 (4): 437-457.

Butler AG (1886) Illustrations of Typical Specimens of Lepidoptera 
Heterocera in the Collection of British Museum. Vol. 6. Taylor and Francis, London, 89 pp. https://doi.org/10.5962/bhl.title.31402

Cerny K, Pinratana A (2009) Moths of Thailand. Vol. 6. Arctiidae. Brothers of Saint Gabriel in Thailand, Bangkok, 283 pp.

Chu H-F (1981) Geometridae. Iconographia heterocerorum Sinicorum 1. Science Press, Beijing, 112-131, pls 29-37.

Hall TA (1999) BioEdit: a user-friendly biological sequence alignment editor and analysis program for Windows 95/98/NT. Nucleic Acids Symposium Series 41: 95-98.

Hampson GF (1895) The Fauna of British India, Ceylon and Burma Vol. 3. Taylor \& Francis, London, 546 pp. https://doi.org/10.5962/ bhl.title. 48423

Han H, Xue D (2011a) Fauna Sinica. Insecta, Vol. 54. Lepidoptera: Geomertridae: Geomertrinae. Scientific Press, Beijing, 787 pp.

Han H, Xue D (2011b) Thalassodes and related taxa of emerald moths in China (Geometridae, Geometrinae). Zootaxa 3019: 26-50.

Hedemann W (1879) Beitrag zur Lepidopteren-Fauna des Amurlandes. Horae Societatis Entomologicae Rossicae 14: 506-516.

Holloway JD (1976) Moths of Borneo with special reference to Mount Kinabalu. Kuala Lumpur: Malayan Nature Society. 264 pp.

Holloway JD (1993) The moths of Borneo: family Geometridae, subfamily Ennominae. Malayan Nature Journal 47 (1-2): 1-309.

Holloway JD (1996) The Moths of Borneo: family Geometridae, subfamilies: Oenochrominae, Desmobathrinae, Geometrinae, Orthostixinae. Malayan Nature Journal 49: 147-326.

Inoue H (1961) Lepidoptera: Geometridae. Insecta Japonica 1 (4): 1-106.

Johnson M, Zaretskaya I, Raytselis Y, Merezhuk Y, McGinnis S, Madden TL (2008) NCBI BLAST: a better web interface. Nucleic Acids Research 36: W5-W9. https://doi.org/10.1093/nar/gkn201

Jung SH (2009) Insects of Seonheul Gotjawal (covered by a rubble flow) in Jeju Island. Journal of Korean Nature 2 (2): 175-182.

Koçak AÖ, Kemal M (2010) Lepidoptera of Thailand. Cesa News 60: $1-184$.

Martens J (2015) Fauna-Himalayan patterns of diversity. in: Miehe G, Pendry C, Chaudhary R (Eds) Nepal. An Introduction to the Natural History, Ecology and Human Environment of the Himalayas. Royal Botanic Garden Edinburgh, Edinburgh, 211-249. https://doi. org/10.1659/mrd.mm194

Mironov VG, Belyaev EA, Vasilenko SV (2008) Geometridae. In: Sinev SY (Ed.) Catalogue of the Lepidoptera of Russia. KMK Scientific Press, St Petersburg, 190-226.

Monastyrskii AL, Devyatkin AL (2000) New taxa and new records of butterflies from Vietnam. Atalanta 31 (3/4): 471-492.

Moore F (1868) On the lepidopterous insects of Bengal (tribe Geometres et al.). Proceedings of the Zoological Society of London 3: 612-686.

Parsons MS, Scoble MJ, Honey MR, Pitkin LM, Pitkin BR (1999) Geometrid Moths of the World: a Catalogue (Lepidoptera, Geometridae). CSIRO, Collingwood, $1016 \mathrm{pp}$.

Prout LB (1912-1916) The Palaearctic Geometrae. In: Seitz A (Ed.) The Macrolepidoptera of the World. Vol. 4. Verlag A. Kernen, Stuttgart, 1-479.
Prout LB (1916) New Indo-Australian Geometridae. Novitates Zoologicae 23: 191-209.

Prout LB (1920-1939) Die Gross-Schmetterlinge des Indoaustralischen Faunengebietes. Die Indoaustralischen Spanner. In: Seitz A (Ed.) Die Gross-Schmetterlinge der Erde 12. Verlag A. Kernen, Stuttgart, 5-292.

Prout LB (1935) New Geometridae from East Java. Novitates Zoologicae 39: 221-238.

Ratnasingham S, Hebert PDN (2007) BOLD: The Barcode of Life Data System (www.barcodinglife.org). Molecular Ecology Notes 7 (3): 355-364. https://doi.org/10.1111/j.1471-8286.2007.01678.x

Robinson GS (1976) The preparation of slides of Lepidoptera genitalia with special reference to the Microlepidoptera. Entomologist's Gazette 27 (2): 127-132.

Sambrook J, Fritsch EF, Maniatis T (1989) Molecular Cloning: A Laboratory Manual, 2nd edition. Cold Spring Harbor Laboratory Press, New York, 1626 pp.

Schauff ME (Ed.) (2001) Collecting and preserving insects and mites: techniques and tools. Systematic Entomology Laboratory, National Museum of Natural History, USDA, Washington, DC, 68 pp.

Simon C, Frati F, Beckenbach A, Crespi B, Liu H, Flook P (1994) Evolution, weighting, and phylogenetic utility of mitochondrial gene sequences and a compilation of conserved polymerase chain reaction primers. Annals of the entomological Society of America 87 (6): 651-701.

Smetacek P (2008) Moths recorded from different elevations in Nainital district, Kumaon Himalaya, India. Bionotes 10 (1): 5-15.

Spitsyn VM, Bolotov IN, Gofarov MY, Vikhrev IV, Bolotov NI (2015) First record of Nyctemera adversata (Schaller, 1788) and N. carissima (Swinhoe, 1891) (Lepidoptera, Erebidae, Arctiinae) from Myanmar. Check List 11 (4): 1687. https://doi.org/ $10.15560 / 11.4 .1687$

Stüning D (2010) Two new species of the Plutodes costatus-group from the Philippines and Indonesia (Lepidoptera, Geometridae, Ennominae). Bonn Zoological Bulletin 57 (1): 75-83.

Suzuki T, Jindo U, Sakamoto Y (Eds) (2015) An Identification Guide of Japanese Moths. http://www.jpmoth.org. Accessed on: 2016-7-15.

Swinhoe C (1892) I. New species of Heterocera from the Khasia Hills. Part II. Transactions of the Entomological Society of London 40 (1): $1-20$.

Swinhoe C (1893) New species of Oriental moths. Annals and Magazine Natural History 12 (69): 210-225. https://doi.org/ $10.1080 / 00222939308677607$

Warren W (1893) On new genera and species of moths of the family Geometridae from India, in the collection of H. J. Elwes. Proceedings of the Zoological Society of London 2: 341-434.

Warren W (1894) New species and genera of Indian Geometridae. Novitates Zoologicae 1 (3): 678-682.

Warren W (1897) New genera and species of Drepanulidae, Thyrididae, Epiplemidae, Uraniidae and Geometridae in the Tring Museum. Novitates Zoologicae 4: 195-262. 